\title{
Re-claiming (Dis)ability through Performance: The Significance of Self-representation in Kinshasa, D.R.Congo
}

\author{
Jori DeCoster \\ Leuven, Belgium
}

\begin{abstract}
This article discusses a specific part of my ethnographic data which was collected during anthropological research in Kinshasa, D.R.Congo, between 2010 and 2014. The research focuses on people with a physical disability and their everyday day life in the urban environment of Kinshasa. The text briefly reflects on representations posited about the 'Other' and wants to direct attention especially to non-Western representations of people with a disability. Here I will mainly explore the tension that exists between an overall negative discourse about people with a physical disability in Kinshasa on the one hand and people with disabilities' self-representation through performance (theatre in this case) on the other hand. In a city where people with a disability deal with different patterns of social and spatial isolation and exclusion on a daily basis, theatre performance opens up a new space through which creatively crossing social barriers becomes thinkable.
\end{abstract}

\section{Keywords/terms:}

Disability, performance, representation, city space, identity

Correspondence information:

Jori.DeCoster@soc.kuleuven.be 


\section{Introduction}

This text explores the tension that exists between an overall negative discourse about people with a physical disability in Kinshasa (and a number of representations which relate thereto) on the one hand and people with disabilities' self-representation through performance on the other hand. The topic of performance has an extensive literature. In this text 'performance' does not just signify 'performing acts' but here it also refers to the performative turn in anthropological research. In The presentation of Self in Everyday Life (1956) Erving Goffman broadly defined performance as an everyday interaction that influences other people (an audience). It is through performance that social identity is established. Describing performance in the context of postcolonial Zaïre, Johannes Fabian states the following:

"No, the kind of performances we find in popular culture have become for the people involved more than ever ways to preserve some self-respect in the face of constant humiliation, and to set the wealth of artistic creativity against an environment of utter poverty. All this is not to be dismissed off-hand as escape from reality; it is realistic praxis under the concrete political and economic conditions that reign" (Fabian 1990, p.19).

In this text I will focus on theatre as a form of resistance, even activism, against a public discourse about people with a disability that exists in Kinshasa. I use two theatre companies as an exemple to discuss how people with a disability use creative space or performance to an audience of outsiders as a tool to negotiate and challenge existing discourses about people with a disability in society.

The text will start with a discussion about disability in the context of Kinshasa. I will especially focus on the presence of people with a physical disability (in French 'personnes vivant avec handicap' or 'pvh') in the city. After this I will resume with a brief outline of my methodology which includes ethnographic fieldwork. To give you an insight into the tensions that often came up during my fieldwork between discourse, everyday life and (self)-representation I will include an ethnographic vignette. What follows is a brief reflection on representations posited about the 'Other' as well as directing attention to the current lack of research on non-Western representations of people with a disability. Finally, I will return to the ethnographic vignette and discuss two theatre companies. I will interpret their act of self-representation as being one of social activism.

\section{Setting the Scene}

Kinshasa is here described within the context of rapid globalization. The city is quickly changing and its inhabitants are constantly on the move. In the absence of stable state governance most inhabitants of Kinshasa ('Kinois') in general, but pvh particularly, organize their daily lives through activities in the informal or 
'second' economy (see e.g. MacGaffey 1997). The public often considers these activities as 'mendicite' (begging). Due to the precarious state of the country, its citizens are forced to fend for themselves and their families. In common Kinois knowledge this is expressed as kobeta libanga or "to break the stones" or in general by making reference to famous article 15: "se débrouiller" "the requirement to fend for yourself"). ${ }^{1}$

Within this context people with a disability are mostly thought of as not being capable to fend for themselves and are often perceived either as a burden or as social parasites. The general discourse is often negative, includes feelings of pity and shame, but also fear. Particular people with a disability are also, to some extent, related to the practice of witchcraft. The lay public often describes them as being aggressive, violent or overcompensating, even 'choleric'. A number of them (especially musicians) are perceived as drug abusers. Many research participants with an impairment often spoke about living in poverty and about being patronized, mocked and marginalized.

The high number of people with a disability ${ }^{2}$ results among others from the ongoing instability of the country and its capital ${ }^{3}$. There is a lack of sufficient data (such as nationally recognized figures) about disability in D.R.Congo in general and in relation to poverty or schooling more specifically (WHO and World Bank 2011; Phos 2011). Opportunities for people with a disability to fully participate in society through education, marriage and employment are severely constrained. It's a situation from which it is hard to escape due to the accumulative effects of being disabled in D.R. Congo. People with a significant impairment are often to be found at the margins of society, in very temporary and peripheral places in the city. They are, for instance, often found on the streets or living in high numbers together in contemporary, ramshackle housing such as buildings that are momentarily not used by the State or the Church.

There are many barriers, both physical and social, to participation on equal footing in the city, which have to be crossed and transgressed on a daily basis. On top of inaccessible city infrastructure and services there is also a lot of ambiguity at the level of the government concerning the rights of people with a disability. Against the background of the 1999-2009 African Decade of Persons with Disabilities and its extension to 2010-2019 people with disability's rights still need to be fully recognized in D.R. Congo. President Kabila only ratified the 1993 United Nations Convention on the Rights of Persons with Disabilities in 2013. For now only article 49 of the country's 2006 constitution explicitly offers some guarantees 4 . Concurrently the law (including article 49) remains very ambiguous and opens up a space for public and personal interpretation of specific rights. I hold that this leads to a number of phenomena that add to the negative discourse about people with a disability.

According to Devlieger (2011) Kinshasa's infrastructures to support pvh are not 
State related but mainly philanthropical and date back to the colonial period or the contribution of a very high number of national and international NGO's 5 . The section that follows my methodology outline will examen how pvh deal with different patterns of social and spatial isolation and exclusion in the city on a daily basis.

\section{Methodology}

This article discusses a specific part of my ethnographic data which was collected during anthropological research in Kinshasa, D.R.Congo. The research focuses on people with a physical disability and their everyday day life in the urban environment of D.R.Congo's capital. It involves a pluralistic methods approach which is qualitative and inductive and relates anthropology to Disability Studies (Kasnitz and Shuttleworth 2001). Fieldwork was conducted in Kinshasa over four visits undertaken between 2010 and 2014. The data in this text are especially supported by fieldwork during January-March 2014 which consisted of participant observation, interviews and focus group discussions. The research was conducted at (living and vocational educational) centres, at people's homes and at specific public places in Kinshasa. All participants were individuals who self-identified as a person with a physical disability or any of the related terms that are applicable in Kinshasa (e.g. 'ebosono', 'bamuela', 'baba', 'koka' (in Lingala); 'kilema' (in Kiswahili); 'kikata' (in Kikongo) and 'bulema' (in Tshiluba)). In this text I will use the term pvh as this is a general word that is used in Kinshasa to refer to people with a disability (short for, in French, 'personnes vivant avec handicap').

During fieldwork I was always in search of visual material and took pictures, drew, collected material, visited artists and discussed the material with them. Some of these images you will find in this text. However, I also encountered a number of people with a disability who creatively produced paintings, danced and held theatrical plays. Their acts of performance through which they presented themselves stood in strong contrast to my observations of their participation in the public sphere on a daily basis and a negative discourse that exists in Kinshasa about people with a physical disability.

In the next part I would like to shed some light on my research with people with a physical disability in Kinshasa by describing two related events that happened during fieldwork. Kapchan mentions that "in its concern with a self-critical methodology that takes account of its effects in the world, ethnography is first and foremost performative - aware of itself as a living script in which meaning is emergent" (Kapchan 1995, p. 484). In the same text Kapchan makes reference to anthropologist Johannes Fabian who explains ethnography as a "coproduced performance' or shared experience. Although I shared the experience with a number of people I have known for some time I wrote the following ethnographic vignette from my own perspective as a white, female researcher without a 
disability.

\section{Notes from the field}

I was not completely sure what to expect as I accompanied Céderique, my guide, through a loud and hectic urban environment only to finally arrive at a secluded haven, peaceful and quiet, namely St. Anne's Church in the Gombe district of Kinshasa. We had an appointment with a theatre group which consisted mostly of people with a physical disability. The excitement I felt at the prospect of meeting a group of actors, who would go through a full rehearsal of their upcoming play, the first I had observed in several visits to Kinshasa since 2010, quickly began to wane.

It had started drizzling by the time we finally found just three members of the Troupe de Théâtre 'Ebenezer' 6 sitting outside of the Church, under a tree, one person standing next to a broken plastic chair and two others sitting on tricycles. Other members arrived and warmly welcomed us as we became acquainted and waited for a very long time. Although the theatre group consisted of 21 members (men and women) at the time during which my fieldwork was conducted (February/March 2014) not all participants were able to get there due to the rain, the city's poor infrastructure (roads and transport) and the necessity for money which would require that someone be absent that day.

Although most of the members were enthusiastic about meeting us I could not help but think of the extent to which this 'informal' rehearsal was itself actually being staged. Perhaps this setting created opportunities or at least the dreams of future opportunities for all parties present. Céderique, my guide, was planning to organise an art festival that summer in cité Mama Olive, and was scouting for artistic talents. I was interested in taking ethnographic fieldnotes about people with a physical disability in Kinshasa, D.R.Congo. Moreover, though, I was hoping to experience an unforgettable theatrical event. During our visit I wondered whether this was also true of the members of the theatre group and whether they had expectations towards me, a visitor from Poto (Lingala for Europe) with money, for which there was always a need.

Before long I recognized two theatre members from an informal meeting which took place several weeks previously. Céderique wanted to set up a meeting with the theatre group and to do so we had to ask permission to two of its members ahead of time. I vividly remembered how hot it was that day, now weeks ago, and how I had to keep up and quicken my step in order not to lose sight of both Céderique and his friend Christian, a man on crutches, who guided us through Kinshasa's frontier.

At specific times throughout the week the frontier is the most interesting economic hot spot for people with a physical disability in D.R.Congo's capital 
Kinshasa. Kinshasa's borderzone with neighbouring capital Brazzaville became important for people with a physical disability after Mobutu negotiated their position as merchants with specific benefits (tax reduction and less police harassments) at the border with Brazzaville, R. Congo. The transborder trade as a borderzone phenomenon has however been subject to a number of changes throughout the years. Recent news items about the transborder trade refer to its specific location (it changed location from Beach Ngobila to a less accessible nearby port) and safety issues. (For more information about the transborder trade see Smith 2003; Ganly 2009; Devlieger 2009; Devlieger 2011; Diakiodi 2011; De Coster 2012; Yekoka 2012.) This phenomenon of people with disabilities dominating the border trade between Kinshasa and Brazzaville has been documented many times. A French online news channel FRANCE 24 even named them 'Roix du commerce' in one of their news items.

The atmosphere got more intense and vibrant as we passed many groups of pvh on their way with their commodities to the ferry or sitting together along the path towards the port. Although I was accompanied by people I knew, I approached the customs building, which housed the custom officers and some military police, with some trepidation. People were all navigating safe ways by which to get in and out of the building and avoiding the custom officers' beatings and their chidings. During my fieldwork many people with a disability complained about this kind of force used by officials at the border. Although I was somewhat taken aback by what I was witnessing, there was no time for reflection as I had to follow my two guides into the building, squeezing my body between and alongside other bodies while trying to keep track of my guides. While both of them had passed customs without even a blink of an eye I suddenly felt a hand on my shoulder, holding me back, and was confronted with an unfamiliar face shouting directly into mine. The custom's officer was so agitated that, for a moment, I even forgot where exactly I had put my visa. To my surprise I did not need to look for the official document for very long. Both my guides and a number of other people with a physical disability started to shout right back at the custom's officer. I even saw crutches being raised aloft. Here, at the borderzone, people with a disability were able to help me cross the border without showing any official documents.

The outburst of noise, brutality and confusion was soon forgotten when we moved into a quieter waiting space inside the building to meet the two members of the theatre group. They were waiting for the next ferry to transport their goods to Brazzaville along with a number of their colleagues.

Now, sitting in a plastic chair under the tree next to the church, the rather turbulent event which had occured at the border stood in strong contrast with our visit to this group of people with a disability that were sitting in a circle whilst talking about their theatre project. 
"We started the theatre group because of the way society treats us. Society thinks of us as being unproductive. (...) We have nothing. We suffer from stigmatisation, marginalisation. The government does not help us and our family does not care about us. Even without knowing your situation, people treat you bad when you have a disability. People identify you according to your disability, even when you have studied. We are more than our disability. That's why we started this theatre group." (Interview with theatre group E., March, 2014)

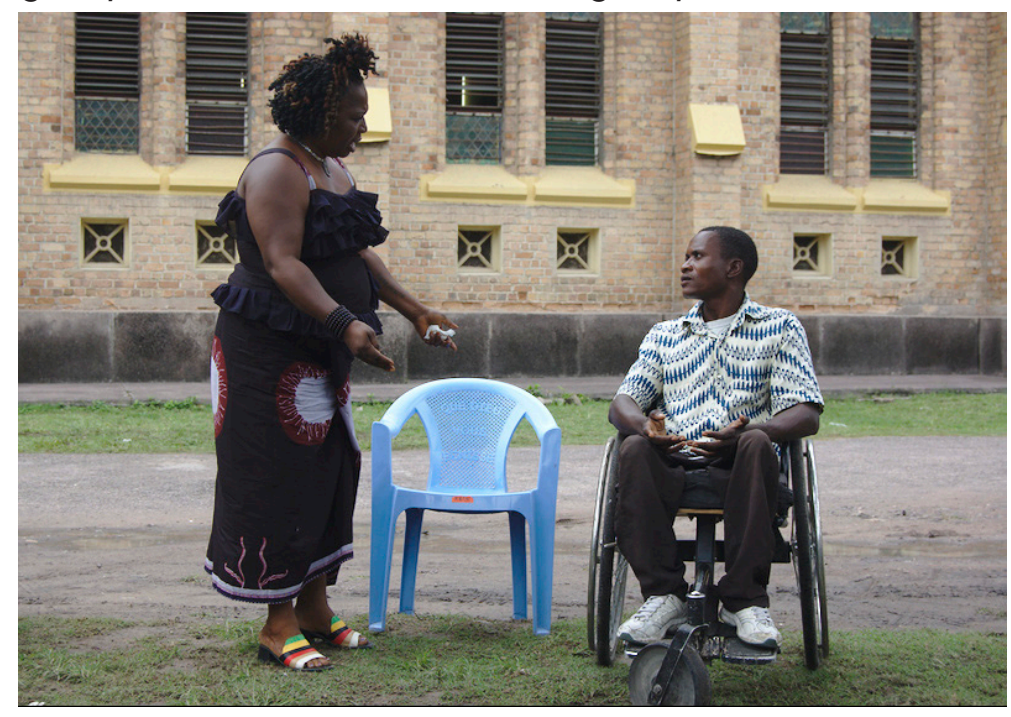

Figure 1: Rehearsal at St Anne's Church

In the interview the members of the theatre group emphasize their feeling of being marginalized and defined by their disability rather than their abilities. This is the reason they started the theatre group in the first place. Part of the performance is to react against a negative discourse that exists in society about people with a physical disability. This connection between disability, discourse and representation is discussed in length in research?. For instance, 'Stiker reminds us that "persons with disabilities, located on the margins of society as they are, have historically taken on the coloration of whatever else is perceived to also lie on the social margins of society."' (Stiker as quoted in Quayson 2007, p.5).

In his work Lennard Davis discusses normalization and reminds us that "the association between what we would now call disability and criminal activity, mental incompetence, sexual license, and so on established a legacy that people with disabilities are still having trouble living down" (Davis 2014, p.7). He questions to what extent there is an hegemony of normalcy that moreover 'extends into the very heart of cultural production' (Davis 2014, p.7).

Although I do agree with Lennard Davis on the importance of questioning normalization I will not directly address aspects of normalization or even biopower in D.R. Congo, Kinshasa, in this text. In this work I want to show the tension that exists between the way people with a disability are often present in Kinshasa's public space, the overall negative discourse that exists about them, and the way pvh present themselves in creative performances such as theatre. 


\section{Occupying city space: Get your act together}

Many pvh cross multiple boundaries and borders to participate in the city and become part of society every single day. In so doing, they turn their bodies into tools through which they gain citizen rights. While navigating the social environment, people with a disability also negotiate their identity as a person with a disability (Siebers 2011). In this part I will give some examples of how people with a physical disability present themselves in Kinshasa's city space to negotiate citizen rights.

Pvh in Kinshasa have developed a number of strategies through which to negotiate oppressive structures and their problematic presence in public space. One very straightforward strategy is by acting as a collective and by forming formal and informal associations and advocacy groups (see e.g. Aldersey 2013). At the socio-political level, for example, pvh are frequently visible as a group in the public sphere. They often turn up in large numbers somewhere in the city to demand specific rights (eg. housing). Smith (2003) gives the well-known example of the transborder trade, which used to be dominated by businesswomen or "Sœurs ya poids" but is now dominated by pvh. This shared space at the border between the Sœurs ya poids and people with a disability was already portrayed in 1983 by popular Kinois painter Monsengwo Kejwanfi or Moke (1950-2001) in his painting 'le port'. The struggle for domination of the transborder trade was eventually won by people with a disability. In 1990 a huge number of pvh presented themselves at the military camp in the capital when Mobutu was present and thus obtained some strong advantages (less police harassment and tax reduction) at the border from this encounter (for more information see Smith 2003; Jacquemot 2011).

Another example in Kinshasa's urban space concerns public transport organized by private individuals who own Mercedes 206 vans that are transformed into public busses. The blue and yellow vans cross the city at high speed - because time is money - often causing accidents, which gives them the name 'esprit de mort' ("Spirit of Death"). Even though no legal document confirms that this law exists, it is still accepted to varying extents, that a number of people do not have to pay for public transport. These people go by the name 'faux têtes' (a code word used between the driver and the fee receiver). These are state officials, people in uniform, elderly people and people with a disability. For pvh this policy often ends up being ignored when trying to catch a bus or in fiercely negotiating one's identity and right, as a pvh, to enter the bus and the payment of the due $\mathrm{fee}^{8}$. Here again, pvh negotiate their identity as a person with a disability to obtain certain rights. As these rights are ambiguous, often not appreciated by the drivers themselves and sometimes even frowned upon by the public some pvh offer to pay. In the following quote Doudou, an artistic director of a theater company, talks about how he encourages his fellow actors with an auditory impairment to present themselves as able-bodied at the bus stop. 
"Faux têtes" for us means that 'the deaf' do not pay the bus fare. When you are at a bus stop with them you tell them that they have to stop signing, but they do not understand. And before you know it the bus has passed you because of their signing. They don't have to pay so they won't take them.

We [our actors] try to make an effort. We always pay. When we are with them we always tell them to pay and we explain to them afterwards that by paying, people will value them. If you have money you should pay. They refuse us so often. They suffer so much. But if you pay then people will appreciate that. (Doudou, talking about his fellow actors/interview March 2014)

A third example of how pvh negotiate unwritten laws is by forming small groups of pvh who traverse the streets of Kinshasa demanding that shop owners support them by paying them a fixed amount of money (indirect taxes). Belgian cineaste Michel Thierry has recorded this phenomenon in his film Le Cycle du Serpent (1992). This example often came up when lay people complained about pvh violent and often even aggressive behavior. After payment, the shop owner will put a paper (an unofficial proof of payment, see figure 2) representing a pvh in a tricycle in his window 9 . If the shop owner refuses to pay the group will start a public uproar.

"Our shop has difficulties to survive. We sell less than last year. (...) They [pvh] come here to ask for money. What are they using it for? Drinks, futilities? I do not know. (...) But we prefer to support the center where they produce things. (...) They use brutalities and it is not good to act in such a way. The State has to take care of them. As a citizen you pay taxes. And then they come to brutalize. Is it really a right? They only use the money for beer. They do this every year and there is no progress in the entire situation." (Shop owner in the municipality of N'Djili)

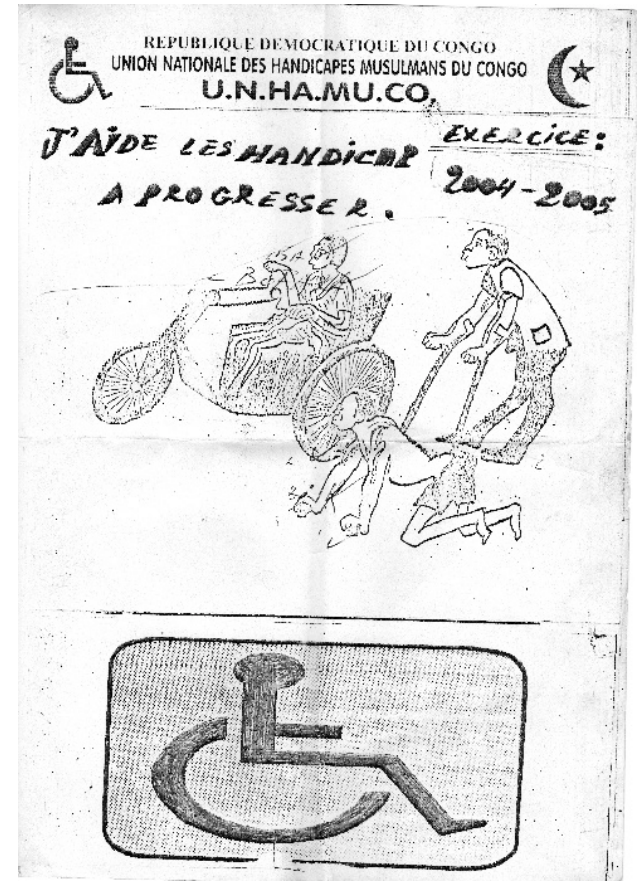

Figure 2: unofficial proof of payment 
As our fourth example I would like to point out that the way people with a disability (re)appropriate city space (DeBoeck 2004) and make a place for themselves in society often incurs a great deal of noise. Kinshasa is a very loud place where the sounds of traffic, public work, music, (religious) celebrations and the voices of ten million people try to speak over one another. Here, I want to refer to the very literal grasping of Kinshasa's very rich soundscape. Many laymen referred to situations by which people with a disability cause some kind of public uproar and raise their voice. When I visited a hospital in Kinshasa one of the doctors complained that people with a disability came to the entrance of the hospital building as a group and started to shout. They were claiming free health care and wanted their claim to be noticed and responded to. The doctor remarked that 'situations' like this happened frequently. There are many examples - some of which have been mentioned previously- by which people with a disability show public dispute or their disenchantment.

However, there are also many examples of a creative and artistic presence of the impaired body in Kinshasa's city space. There are for instance a number of wellknown musicians with a disability such as M'Pongo Love (1956-1990) and Vadio Mambenga (1940-1990) ${ }^{10}$. The best-known example nowadays is Staff Benda Bilili. Global flows and creative outlet allowed the members of music band Staff Benda Bilili, consisting of paraplegics and one shégè (street child), even to move beyond city space or Kinshasa's locality ${ }^{11}$. Not allowed to perform with any local band in Kinshasa, they formed their own 'Orchestra'. The band often takes up a messenger's role and wants to inform people about 'disability' through a number of songs (e.g. their song 'polio'). Both their music and the band members are now crossing international borders. I met them in Brussels in 2010 for an interview and four years later in Kinshasa in their new music studio. I bought their cd in Leuven and saw them again on television and Facebook. Following the success of Staff Benda Bilili many people with a disability (especially men but also women) nowadays hope to earn a living by forming music bands. Additionally, there are also a number of dancers with a disability who are part of music groups in Kinshasa. Scholars, such as Simi Linton $(2006,2014)$, consider dance to be the most radical and transgressive thing that people with a disability can do ${ }^{12}$.

In the last section I will return to my ethnographic vignette and add a second example of a theatre group that is situated in Kinshasa. Both examples show how people with an impairment in Kinshasa use creative performance as an instrument to instigate a dialogue with society about disability.

\section{Re-presenting the Other and Re-claiming (Dis)ability}

Since the time of Edward Said's Orientalism representations of the Other have gone through a long history of deconstruction and the continuous questioning of the production of both images and reality. The influence - positive and negative - 
of images on the way in which people comprehend disability has informed a long tradition of among others Disability Studies scholars (e.g., Zola 1985, Longmore 1985, Gartner and Joe 1986, Nordon 1994, Safran 2001, Enns and Smith 2001, Mitchell and Snyder 2001 and many others ${ }^{13}$ ) who have all distilled a broad variety of harmful, negative depictions of people with disabilities from a broad spectrum of moving images ${ }^{14}$.

For the most part, these readings of disability in narratives (movies, primarily, but also documentaries, photography, paintings, theatre and literature) focus upon Western representations exclusively, neglecting visual representations that originate from an African context for instance ${ }^{15}$. This article will not offer an analysis of the many visual representations that exist of Congolese people with a disability. Instead, I would like to focus on people with disabilities' self-representation, more specifically through performance as discussed in two ethnographic examples. The following examples from Kinshasa show how theatre for pvh opens up new creative avenues that allow them to cross boundaries and to enter into dialogue with society directly.

The theatre group Ebenezer at St Anne's Church do not have their own rehearsal room (only the church garden), costumes, properties, or technical support. They lack most of the material requirements to professionally organize themselves as a company, but have sufficient human resources to create theatre. For the time being they do not earn anything with their spectacle. However, the actors try to be present at the rehearsals. Most of the members make a living by occupying some kind of economic niche, even within the second economy. Some of the actors emphasized that being part of a theatre company gave them a job which they combined with other economic activities such as the transborder trade.

One of the reasons why they started the theatre group is that they are not pleased with the way society perceives them and the way pvh are represented in television shows. This discontent brings them together to enact plays that represent their perspective.

"The reason we founded the theatre group is because of the way our society and our family treat us. (...) We are considered to be unproductive. It is always the same thing. Even the government has the same attitude towards us. They even question why a child with a disability needs to be scholarized. The same attitude in the shops. They identify us according to our disability. We are considered 'invalide'. We use theatre to sensitize society about what it means to be a person with a disability. (...) Nobody wants to be a person with a disability, but in theatre the disabled are never played by a person with a disability. They should be played by a person with a disability, not by a 'valide' who plays this role. (...)" (S., actress and entrepreneur)

While I am present at their rehearsal the members of the theatre company play various scenes in which everyday life is shown from their point of view. Often 
these scenes are moralizing, they relate to everyday life and reflect upon for instance family relations or life events such as marriage. As an example of their work I offer a summary of three scenes:

One scene depicts a woman with a disability who is asked by a man to become his wife but his family does not accept her because she has a disability. The family prefers another wife without a disability for the man. This other woman turns out to be lazy, bossy and unfriendly. She has exactly the opposite attitute and personality as the woman with a disability. Thus, in the end the man and his family choose the woman with a disability.

A second scene (figure 3) depicts a mother in a tricycle who is having a discussion with her son. Instead of going to school her son is always on the street. She however needs a son who can take care of her and she blames him for being on the street and therefore very soon in prison from where he cannot properly take care of her.

A third scene is about a man with a disability who has his own shop. Each day a woman visits his shop a flirts with him. She does not, however, know that he is disabled because he is standing behind the counter. One day the woman discovers that the man has a disability. This was the last day the woman visited the shop.

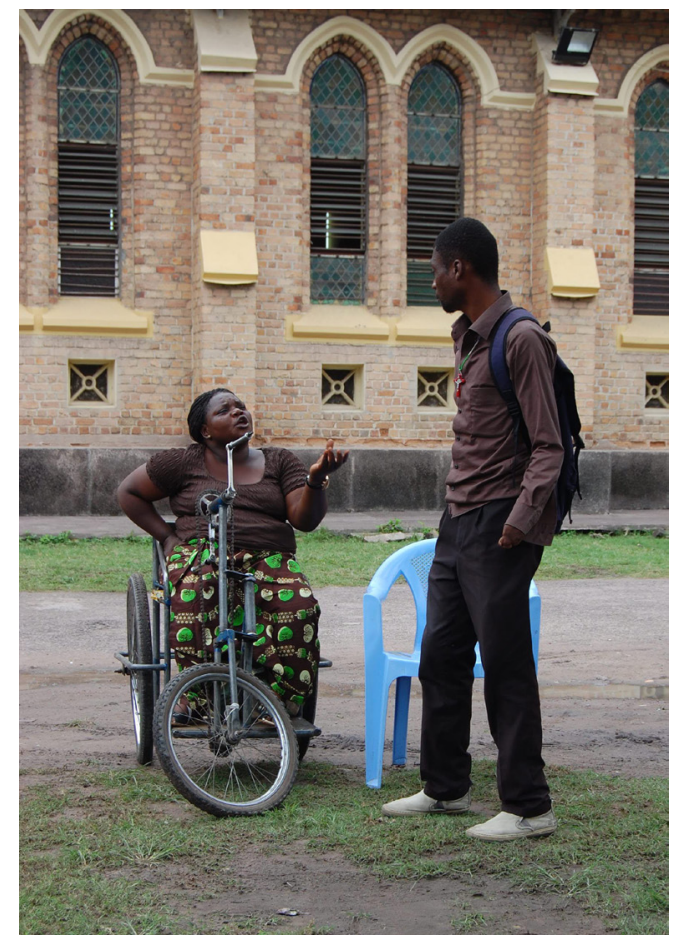

Figure 3: Scene 2 'mother and son'

Introducing group "Mabin’a Maboko" (La danse des mains/ Dancing Hands). This second theatre company consists of a majority of actors with an auditory impairment and only four actors who have their full auditory ability. The theatre 
company is more professional than the one depicted in the first example and receives more support. This theatre project came into existence for reasons similar as described in our first example. The theatre company grew out of CPPS ${ }^{16}$ (Centre de Production des Programmes et Supports de sensibilisation des Sourds), a centre that is coordinated by Freddy $\mathrm{M}^{17}$. As a social scientist Freddy started to reflect on the portrayal of people with a disability on Congolese television. He wondered about the extent to which pvh could really see themselves in terms of the characters being displayed in soap series. He began collaborating with a local school for people with an auditory impairment and founded the theatre group "Mabin'a Maboko" together with artistic director Doudou N., who already had theatre experience. For them, theatre opens up a new space through which creatively crossing social barriers becomes thinkable.

Both Freddy and Doudou do not identify themselves as pvh. Because of their collaboration with pvh they understand the way pvh experience life in Kinshasa. Freddy and Doudou explain that for people with an auditory impairment in Kinshasa, their disability not only signifies a general communication problem with other members of society. This specific kind of disability for instance also decreases safety and increases insecurity (cfr. dangerous traffic conditions, but also health information). Through the theatre project the actors translate otherwise unaccessible information (eg about aids/HIV) into understandable messages for people who have an auditory impairment. Providing accessible information was one of the first objectives of the company.

A second objective of CPPS which is realized through the theatre project is the sensibilisation of Kinshasa's inhabitants about their family members, colleagues, and neighbours with an impairment. In a group discussion Freddy, Doudou, a translator (a teacher at the local school) and the actors mention that having an auditory impairment is one of the most severe impairments one could have in Kinshasa:

"The pvh are often perceived as retarded. They are completely closed off from communication. Often the people who know our centre come here when they feel sick and can't explain what is wrong to their family. (...) We have difficulty obtaining jobs and often do very 'low' work (sewer cleaning). A person with paralysis can perhaps still participate in school, but a deaf person cannot. There are people with a visual impairment who go to university. No person with auditory problems goes to university here." (Excerpt group discussion with Doudou and the company)

Their theatre project also includes a film 'justice injuste' with several scenes from everyday life of a girl with a auditory impairment who lives with her brother. All scenes portray problems related to being a person with an auditory impairment. Although the film includes some comical sketches the purpose of the media project is to create awareness. A number of scenes show or suggest (verbal, 
physical, sexual) abuse of the girl by her own brother. During the time of my visit I heard similar stories about girls who were deaf-mute and were abused 'in silence'. The short film was broadcasted on televison to create awareness about several problems people with an auditory impairment are confronted with. By involving them with theatre CCPS also wants to show that pvh are capable and productive. Therefore, the most important objective of putting plays on is to valorise people with a disability and to show them as productive actors in society.

"We started from the principle that to have value and importance in society, you have to produce something and add something to society. We start from an artistic basis. We give to society as artists." (Doudou)

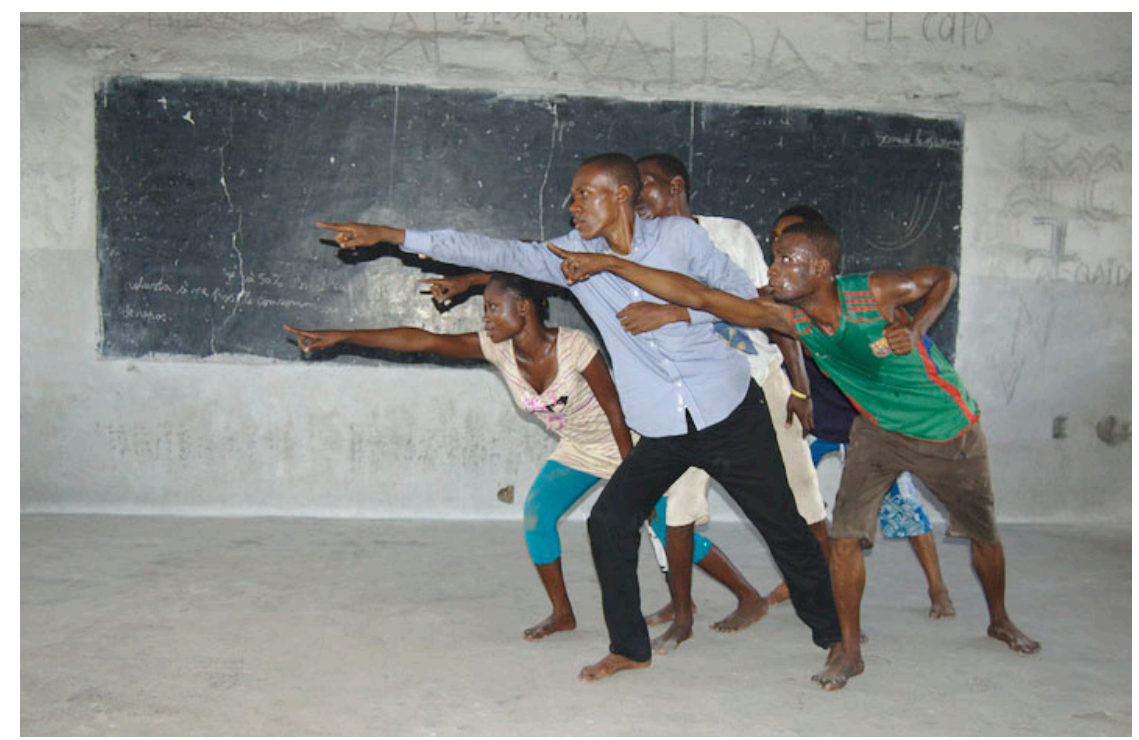

Figure 4: Rehearsal in a school building

Moreover, the theatre project wants to demonstrate that people with and without a disability can collaborate. Doudou and the actors emphasized several times that the company consists of actors with and without an auditory impairment and that the theatre project, therefore, is an example of inclusion. Doudou explained in an interview that the company would also love to integrate artists with a visual impairment into the theatre plays but that, at the moment, this task was still too difficult. However, by creating performances (theatre plays but also dance and a yearly festival) the company already claims to succeed in attracting a broad, mixed audience.

Both Freddy and Doudou are journalists for Human Rights in D.R.Congo. Consequently, their promotion of pvh through theatre also includes a Human Rights perspective that is enforced by connecting their theatre plays to CPPS but also a yearly organized festival dedicated to people with a disability. In the next paragraph I will briefly describe the history of this festival and outline how several connections with an international community of artists with a disability moved the group forward into new directions. 
In line with CPPS and "Mabin'a Maboko" Freddy and Doudou were invited by a Rwandan-Belgian theatre producer to co-organize an international festival dedicated to artists with a disability. Because the Rwandan-Belgian producer has his company in Brussels the festival took place in Belgium. This first edition was entitled "Off Off" and was organised in 2010. Due to budgetary problems, the company could not participate but instead sent in a film showing one of their plays. The following year, 2011, the "Off Off" festival was organized in Tunisia. Not all members of the company could travel. The play was therefore rewritten for only two actors so that the company could still participate in the festival in Tunisia. As founder of CPPS Freddy received the Communication for Social Change Award from the University of Queensland, Australia in 2011.

The continuous confrontation with problems to participate in the festival abroad made Freddy and Doudou decide to organize a third edition in Kinshasa in 2012. During this edition there was an interesting international collaboration between Mabin'a Maboko (D.R.Congo, Kinshasa) and visiting theatre group "Compagnie Zacharie" from neighbouring Brazzaville, R. Congo. Both companies performed one play called "la déclaration universelle des droits de l'homme" and a second play entitled "De la nausée" together. For the fourth edition (2013) the festival was visited by R.G., the artistic director of DaDaFest in the U.K. Being a woman with an auditory impairment herself, R.G. participated in the festival, discussed the situation of people with an impairment in the U.K. in a symposium afterwards and invited the group to participate at the DaDaFest ${ }^{18}$ in Liverpool. However, a lack of finances had made participation of the Company at the DaDaFest something of an impossibility.

In 2014 the festival showed a movie that was made by the theatre group in collaboration with a Canadian filmmaker André Saint-Pierre, who followed the group for nine months. The film project entitled "Mabin'a Maboko" allowed the company to travel to neighbouring province Bas-Congo and to play in several villages. For most of the actors this journey was their first visit outside the capital. It was also the first time they met other people with an auditory impairment outside Kinshasa. The road movie is complemented by several narratives from the actors about their life as a person with a disability in Kinshasa.

Although the Rwandan-Belgian coordinator of the "Off Off" festival participated during the fourth edition the Congolese version was eventually renamed Festival International Handicap Alternative (FIHA) in order to officially claim its independance as a festival. During this edition the company played "Lumière dans les ténèbres", a play based on the life of Helen Keller. The organisors also formally decided to combine the spectacle of the festival with conferences and debates dedicated to current social themes relating to pvh in Kinshasa. The conference in 2014, for example, was entitled "Artiste en situation d'handicap, acteur du développement" and focussed on artists with an impairment as actors 
of development.

The Canadian movie, the festival, a number of media projects, the theatre plays, the dance sessions accompanied by drum, and the actors' narratives in general all reflect the importance of performance in the lives of all the members of "Mabin'a Maboko". In a group discussion the actors first of all emphasized that theatre gives them a profession. However, the theatre project also opens up a space in society that enables them to cross particular borders and boundaries and to creatively get into dialogue with society. The theatrical plays started with the objective of informing, sensitizing, and even resulted in connecting the company to an international community that speaks to the necessity for Human Rights. However, during this theatre group's process of growing their performance is, according to Doudou, now also being expressed as art for art's sake.

\section{Conclusion}

Research reveals how forces of modernity and globalization affect the life of people with a disability everywhere. In this text I focused on the context of Kinshasa, D.R.Congo, where pvh re-inscribe themselves in city space despite encountering persistent isolation and exclusion. By participating in city space, however, pvh also negotiate their (citizen) rights as a person with a disability. In doing so, pvh often have to be agile and loud. Therefore their behavior is in many instances perceived as violent or aggressive. All this adds to the negative discourse about pvh in Kinshasa.

An improvement of pvh everyday life should therefore not just include a discussion of representations only but should also deal with economic conditions and socio-political reality. Actors with a disability repeatedly mentioned that theatre offers them the opportunity to have a job, to collaborate with other people on shared projects and to respond to the negative perception that exists about them in society.

Within city space a number of pvh have found creative avenues to open up the dialogue with society. Theatre as performance can be understood here as a creative space where pvh negotiate not only their representations but also their presence in general in society. More specifically, both theatre companies want to change the negative perception of pvh by re-claiming (dis)ability and want to show their struggle with society's disabling conditions. For these artists with a disability theatre opens up a way to overcome some of society's obstacles and to create opportunities for change.

However, life in D.R. Congo's capital confronts both theatre groups with a lack of theatre infrastructure, budgetary problems, small audiences and an uncertain future. Further research could examine whether this dialogue indeed works in both ways and to what extent the message is received and acted upon. Although 
a number of connections and activities contain the promise of new pathways for the future, this future still remains very fragile and uncertain.

\section{Notes}

1 'Article 15' is an article that only exists in public discourse and has no legal ground. Article 15 actually refers to the song "Article 15, beta libanga" by Congolese musician Pepe Kalle and which talks about the difficulty of life in Kinshasa.

2 Official figures are almost non-existing. Local organization FENAPHACO, Handicap international and PHOS mention around 10 percent of the total population.

${ }^{3}$ This 'instability' is amongst other caused by the ongoing war in the eastern part of the country, political conflicts in general (e.g. due to elections), poverty, lack of different kinds of infrastructure and so on. In D.R. Congo disability is also linked to malnutrition and accidents.

${ }^{4}$ Article 49: "Aged and handicapped persons have the right to special measures of protection with regard to their physical, intellectual and moral needs. The State has the duty to promote the presence of handicapped persons in national, provincial and local institutions. An organic law determines the conditions for the application of this right." (The Constitution of the Democratic Republic of the Congo, 2006)

${ }^{5}$ For more information about supportive infrastructures, such as specific institutions, please read among other: Devlieger and Nieme (Eds). 2011. Handicap et Société africaine: culture et pratques. L'Harmattan.

${ }^{6}$ The theatre group named itself after a religious group.

7 See for instance Staples, James (2012) 'Culture and Carelessness: Constituting Disability in South India' Med Anthropol Q. 26 (4): p. 557-74 as an interesting discussion of discourse.

8 Pvh react to this 'unwritten' law in various ways; some refuse to pay, others insist on paying. Most of the time the outcome depends on the pvh but also the fee receiver. During one of these bus rides I witnessed a number of passengers demanding the receiver to let my colleague (a woman without arms) ride for free. The unwritten law is also claimed from time to time by people who are not perceived as pvh by others, but who identify themselves as such. Thus, the ambiguity leads to much tension and discussion. 
${ }^{9}$ An interesting element to explore is the correlation with religious identity. A number of participants but also the illegal document (figure 2) states that especially shop owners with an Islamic background are approached.

10 In Kinshasa the name 'Vadio' is sometimes used to refer to pvh.

11 Their succes even allowed them to move away from the public locality of the city's zoo where Staff Benda Bilili organized their music repetitions or Kinshasa's streets where they were forced to live after their shanty home burned down. Their success includes a number of cd's, two films were made about them, they received music awards and had several international tours. In his painting 'Les Défis de la Mondialisation' (2011) popular Congolese painter Chéri Cherin portrays them as a paradox of globalisation. Text added to the painting mentions 'agence courage / grand marathon du siècle.' The painting depicts a marathon lead by president Obama in a plane and followed by members of Staff Benda Bilili, sitting atop a rather luxurious motorized tricycle.

12 Here, I would like to make reference to Thomson, R.G. Staring Back: SelfRepresentations of Disabled Performance Artists. In this text I do not focus on the performative body itself as something that disrupts the order of things in relation to the gaze. Here the focus is on public space and participation.

13 See e.g., Safran (1998); Burch (2005) for literature reviews.

14 Interesting analyses of images depicting pwd (often with an emphasis on the gaze) in photography, paintings, and literature for instance are presented in the work of Rosemary Garland Thompson (1997, 2006, 2009). See also e.g., Quayson (2007).

${ }^{15}$ Exceptions to this rule include the colonial depiction of pwd in Pitaniko (Devlieger 1998) or analyses of disability in a number of African films or documentaries more generally (Devlieger and De Coster 2009; Nepveux 2010; Phambu Ngoma Binda 2011; Lipenga 2014a, 2014b) but they remain limited, considering the large body of knowledge to which disability lays claim.

16 http://cpps-rdc.com/

17 Freddy M is a communication scientist who wrote his thesis on the participation of people with an auditory disability during the 2006 elections. "They started to sensitize people to vote, but nobody sensitized people with auditory impairments. Often they didn't follow election programmes or propaganda but just voted for the best picture" (Freddy M., interview March 2014).

18 See also: $h t t p: / / w w w . d a d a f e s t . c o . u k /$ 


\section{Bibliography}

ALDERSEY, H. M. (2013) "Disability advocacy in Kinshasa, Democratic Republic of the Congo." Disability \& Society. 28(6). p. 784-797.

Benda Bilili! (2009) Documentary. Directed by Renaud Barret and Florent de la Tullaye. (DVD) TWINPICS.

Constitution de la République démocratique du Congo. 2006. Kinshasa.

DAVIS, L. (1997). "Constructing Normalcy: The Bell Curve, the Novel, and the Invention of the Disabled Body in the Nineteenth Century." In The Disability Studies Reader, ed. Lennard Davis, 9-28. New York: Routledge.

DE BOECK, F. (2004) Kinshasa. Tales of an Invisible City, Antwerpen: Ludion.

DE COSTER, J. (2012) 'Pulled towards the Border : Creating a Disability Identity at the Interstices of Society.' Disability Studies Quarterly. 32(2). p. 1-12.

DEVLIEGER, P. (1998) "Representations of Physical Disability in Colonial Zimbabwe: The Cyene Mission and Pitaniko, the Film of Cyrene." Disability and Society. 13(5). p. 709-724. doi: 10.1080/09687599826470.

DEVLIEGER, P. and DE COSTER, J. (2009) "Disability in African Films: A semiotic analysis.” Semiotica. (174). p. 145-164. doi: 10.1515/semi.2009.030.

DEVLIEGER, P. (2009). “Disabled People Trading Across the Congo River.” In Ine Gevers, ed. Difference on Display: Diversity in Art, Science \& Society. p. 330-336.

DEVLIEGER, P. (2011a) Lecture de la société kinoise à travers certains phénomènes de handicap. In: and Nieme (eds.) 2011. Handicap et société africaine: culture et pratiques. Paris: Harmattan.

DEVLIEGER, P. and NIEME, L., eds. (2011) Handicap et société africaine: culture et pratiques, Paris: Harmattan.

DIAKIODI, A. (2011) “L'Intégration des personnes ayant un handicap dans le monde du travail en Afrique noir.” In: and Nieme (eds.) 2011. Handicap et société africaine: culture et pratiques. Paris: Harmattan.

ENNS, A. and SMIT, C. R. eds. (2001) Screening Disability: Essays on Cinema and Disability, Lamham: University Press of America.

FABIAN, J. (1990) Power and Performance. Ethnographic explorations through proverbial Wisdom and Theatre in Shaba, Zaire. Wisconsin: The University of 
Wisconsin Press.

GARTNER, A. and JOE, T. eds. (1986) Images of the Disabled/Disabling Images, New York: Praeger.

Handicapés et rois du commerce FRANCE 24. (Accessed 28th October 2014. http:// www.france24.com.)

KASNITZ, D. and SCHUTTLEWORTH, R. P. (2001) Introduction: Anthropology in Disability Studies. Disability Studies Quarterly. 21(3). p. 2-17.

LIPENGA, K.J. (2014a) "Narrative enablement: constructions of disability in contemporary African imaginaries." PhD diss., Stellenbosch: Stellenbosch University.

LIPENGA, K. J. (2014b) "Disability and Masculinity in South African autosomatography." African Journal of Disability. 3(1). p.1-9. doi: 10.4102/ajod. v3i1.85

LONGMORE, P. (1985) Screening Stereotypes: Images of Disabled People in Television and Motion Pictures Social Policy. 16(1). p. 31-37; reprinted in Longmore, Paul K. 2003. Why I burned My Book and Other Essays on Disability. Philadelphia: Temple University Press.

GANLY, K. (2009) "Disabled Congolese Find Ways to Thrive." GlobalVoices Online, May 17, 2009. (Accessed 20th november 2014: http://globalvoicesonline. org/2009/05/17/disabled-congolese-find-ways-to-thrive/ )

GOFFMAN, E. (1956) The Presentation of Self in Everyday Life. New York: Doubleday.

HEVEY, D. (1991) "From Self-love to the Picket Line: Strategies for Change in Disability Representation". Disability Arts and Culture Papers. Transcripts of a Disability Arts and Culture Seminar: November 20th 1991. Edited by Sarah Leeds. Published by Shape Publications. See also Disability, Handicap \& Society. 8(4). p. 423-429.

"Hoe inclusief is onze ontwikkelingssamenwerking? Handicap in het Belgische ontwikkelingsbeleid" MO/Mondiaal Nieuws. nr. 69 - april 2012. (accessed 20th November 2014: www.mo.be/papers)

Invitation to Dance. (2014) Documentary. Directed by Simi Linton and Christian von Tippelskirch. (DVD) 
JACQUEMOT, P. "Kinshasa, le mégalopole sans cesse réinventée". November 2011. Les notes de L'IRIS (Institut de Relations internationales et strategiques).

KAPCHAN, D. (1995) "Performance" The Journal of American folklore 108(430). P 479-508.

LINTON, Simi. (2006) My Body Politic. Ann Arbor: University of Michigan Press.

Mabina Maboko, la danse des mains. (2013) Documentary. Directed by SaintPierre, André. (DVD) Québec: Les Productions Kinesis.

MACGAFFEY, J. (1997) "Paradoxes, Problems and Opportunities in Zaïre." American Anthropologist. 99(2). p.369-379. Doi: 10.1525/aa.1997.99.2.369.

MITCHELL, D. T. and SNYDER, S. (2001) The Uneasy home of Diasbility in Literature and Film. In: Handbook of Disability Studies by Albrecht, Geelman and Bury (eds.). SAGE Publications.

NEPVEUX, D. and SMITH, E. (2010) "Producing African Disability Through African Film: Emmanuel's Gift and Moja Moja." Journal of Literary \& Cultural Disability Studies. 4(3). p. 237-54. Doi: 10.1353/jlc.2010.0011.

NORDON, M. (1994) Cinema of Isolation: A History of Physical Disability in the Movies, New Brunswick, NJ: Rutgers University Press.

PHOS 2012, "Hoe inclusief is onze ontwikkelingssamenwerking? Studie van handicap in het federaal ontwikkelingsbeleid. (Accessed 20th November 2014: www.phos.be)

QUAYSON, A. (2007) Aesthetic Nervousness: Disability and the Crisis of Representation, New York: Columbia UP.

SAFRAN, S. P. (1998) 'The First Century of Disability Portrayal in Film: An Analysis of the Literature'. The Journal of Special Education. 31(4). p. 467-479.

SIEBERS, Tobin (2011) Disability Theory. Ann Arbor, MI: University of Michigan Press.

SMITH, S. (2003) Le Fleuve Congo. Actes Sud.

THOMPSON, R.G. (1997) Figuring Physical Disability in American Culture and Literature. Columbia University Press.

THOMPSON, R. G. (2006) "Ways of Staring." Journal of Visual Culture. 5(2). p. 173192. doi: $10.1177 / 1470412906066907$. 
THOMPSON, R. G. (2009) Staring. How we look, Oxford: University Press.

THOMPSON, R. G. (2000) "Staring Back: Self-Representations of Disabled Performance Artists”. American Quarterly. 52(2). p. 334-338.

World Report on Disability. Report by World Health Organization and the World Bank, June 2011.

Yekoka, Jean Félix (2012). Les jeunes commerçantes handicaps moteurs dans la négotiation de la vie entre Brazzaville et Kinshasa (1970-2009). In Michael Bourdillon (Ed.), Negotiating the Livelihoods of Children and Youth in Africa's Urban Spaces. Oxford, UK: Africa Books Collective.

Zaire: The Cycle of the Serpent. (1992) Film. Directed by Thierry Michel. (DVD). First Run/Icarus Films

ZOLA, I. (1985) "Depictions of disability - metaphor, message, and medium in the media: a research and political agenda." The Social Science Journal. 22. pp. 5-17. 